\section{Cultivation and Topdressing Requirements for Thatch Management in $A$ and $G$ Bentgrasses and Creeping Bluegrass}

\author{
John C. Stier ${ }^{1}$ and Andrew B. Hollman ${ }^{2}$ \\ Department of Horticulture, University of Wisconsin, Madison, WI53706-1590 \\ Additional index words. Core aeration, thatch, DW-184, A-4, G-2, Penncross, Agrostis \\ stolonifera, Poa annua var. reptans
}

\begin{abstract}
Empirical observations suggest certain new cultivars of creeping bentgrass (Agrostis stolonifera $\mathrm{L}$.) with high shoot density require more intensive topdressing and core aeration to control thatch compared to less dense cultivars such as 'Penncross'. In addition, a variety of Poa annua var. reptans Hausskn., 'DW-184', has recently been released for putting green use but management requirements are undocumented. The objective of our project was to determine the core aeration and topdressing requirements for thatch management of creeping bentgrass cultivars ' $\mathrm{A}-4$ ', ' $\mathrm{G}-2$ ', and 'Penncross' as compared to 'DW-184'. Plots were established on a sand-based root zone and maintained as putting green turf for 3 years. A factorial treatment arrangement was used to assess the effects of core aeration and topdressing on thatch, topdressing removal, turf quality, and disease. Both 'A-4' and 'G-2' produced more organic matter as (thatch/mat) than 'Penncross' and 'DW-184'. Grass type, core aeration frequency, and topdressing regime affected the amount of topdressing removed by mowing. An interaction between grass type and topdressing regime showed biweekly topdressing with verticutting resulted in less topdressing removal from all grasses except ' $G$-2' compared to monthly topdressing without verticutting. Since no more than $3 \%$ of the topdressing applied was removed from any single treatment, however, the overall impact of grass type, core aeration frequency, or topdressing regime are unlikely to affect turf response. Both 'A-4' and ' $\mathrm{G}-2$ ' provided consistently better quality turf than 'Penncross' or 'DW-184' at $3.2 \mathrm{~mm}$ mowing height, though 'A-4' was more susceptible to dollar spot disease (Sclerotinia homeocarpa F.T. Bennett) than 'Penncross' or ' $G-2$ '. Cultivation and topdressing methods for management of 'A-4' and ' $\mathrm{G}-2$ ' bentgrasses do not differ substantially from 'Penncross' or 'DW-184' creeping bluegrass.
\end{abstract}

Creeping bentgrass, epitomized by 'Penncross', has become the preferred putting green turf since the mid-1950s due in part to its high turf quality and ability to tolerate golf-related traffic. In the early 1980s plants were chosen out of existing 'Penncross' and 'Penneagle' greens from the southern U.S. and used to produce several new varieties of bentgrasses. The new varieties, 'A-1', 'A-2', 'A-4', 'G-1', 'G-2', and 'G-6', were notable for their upright growth, high shoot density, and narrow leaves (Fraser, 1998). Shoot densities exceed 2000 shoots $/ \mathrm{dm}^{2}$ compared to $<1500$ shoots $/ \mathrm{dm}^{2}$ for 'Penncross', allowing the A and $\mathrm{G}$ series bentgrasses to resist invasion by $P$. annua (Beard et al., 2001). The A and $\mathrm{G}$ bentgrasses have good disease resistance (Fraser, 1997) and better summer stress tolerance than 'Penncross' and other conventional bentgrasses (Landry and Schlossberg, 2001)

Received for publication 4 June 2002. Accepted for publication $16 \mathrm{Dec}$. 2002. We are grateful to the Wisconsin Golf Course Superintendents Association and the College of Agricultural and Life Sciences at the University of Wisconsin-Madison for providing project funding, and to Wayne Kussow and Teryl Roper for their reviews prior to submission.

${ }^{1}$ Assistant professor.

${ }^{2}$ Former undergraduate student research assistant.
Their aggressive growth, however, may require a more rigorous management regime than is typically used for 'Penncross' and other less aggressive varieties. Anecdotal data from the southeastern U.S. indicate A and G bentgrasses require a lower mowing height and more frequent topdressing and core aeration than older cultivars (Fraser, 1998). Some concern has been expressed that the high shoot density may prevent incorporation of topdressing below the canopy (Fraser, 1998). A survey of 18 golf course superintendents revealed management practices included a range of topdressing regimes from biweekly to monthly and core aeration from two to six times annually (Fraser, 1998). Unfortunately no peer-reviewed data have been published to confirm the additional management requirements. Lack of information on the actual management requirements has limited the acceptance of the A and $G$ bentgrasses.

The ubiquitous presence of $P$. annua in putting greens has resulted in breeding efforts to produce perennial biotypes suitable for use on putting greens (Huff, 1998; White, 1997). In 1997 the first variety of $P$. апnиa var. reptans 'DW-184'was released for commercial use (White, 1997). Its stoloniferous growth habit earned it the moniker creeping bluegrass (Beard, 1999). Unfortunately, little is known about its performance and management requirements because it is such a new grass type. Many superintendents are reluctant to use creeping bluegrass due to lack of management information and its stigma as a weed species. Miltner et al. (2000) have investigated establishment methods for creeping bluegrass. Dudek and Anderson (1999) reported 'DW184' compared similarly to rough bluegrass (Poa trivialis L.) for overseeding winter-dormant bermudagrass [Cynodon dactylon (L.) Pers. $\mathrm{x} C$. transvaalensis Burtt-Davy] golf greens. Beard (2002) has suggested a generic management regime for $P$. annua var. reptans on putting greens.

The degree of more intensive management for $\mathrm{A}$ and $\mathrm{G}$ series bentgrasses has not been established. In addition, no management requirements have been published for ' $\mathrm{DW}$ 184 ', and information is needed on its ability to perform similarly to new and conventional bentgrasses. The objective of the study was to determine the core aeration and topdressing requirements for creeping bentgrass varieties 'A-4', 'G-2', 'Penncross', and 'DW-184' creeping bluegrass.

\section{Materials and Methods}

Plot preparation. Plots of 'Penncross', 'A4 ', and 'G-2' creeping bentgrasses and 'DW184 ' creeping bluegrass were established with $4.8 \mathrm{~g} \cdot \mathrm{m}^{-2}$ of seed on 10 Sept. 1998 in Verona, Wisc. Plots had a sand-based root zone constructed in 1992 based on U. S. Golf Association(USGA) specifications (USGA, 1993). The organic matter content was $1 \%$ (by mass), $\mathrm{pH}$ 7.8 , phosphorus content was $61 \mathrm{~kg} \cdot \mathrm{ha}^{-1}$, and potassium content was $54 \mathrm{~kg} \cdot \mathrm{ha}^{-1}$. Mowing height was reduced from $8.9 \mathrm{~mm}$ during establishment to achieve a final mowing height of $3.2 \mathrm{~mm}$ during Spring 1999. Turf was mowed six times weekly with a walking greensmower with clippings removed. Only granular fertilizer was used (21-3-12); nitrogen sources were $\approx 20 \%$ water-soluble (urea) and $80 \%$ insoluble (75\% methylene urea and 5\% organic) forms. Plots were fertilized biweekly with $\mathrm{N}$ at 2.4 $\mathrm{g} \cdot \mathrm{m}^{-2}$ following seeding until 15 Nov. 1998 (six applications). Plots were fertilized 10 times in 1999 to aid establishment, using equal increments of $\mathrm{N}$ to supply an annual total of $\mathrm{N}$ at $24 \mathrm{~g} \cdot \mathrm{m}^{-2}$. In 2000 and 2001, turf was fertilized four times annually to provide a $\mathrm{N}$ total of $17 \mathrm{~g} \cdot \mathrm{m}^{-2}$. Plots were irrigated daily to replenish $100 \%$ estimated evapotranspiration (ET) rate using a modified Penman-Monteith equation based on weather data downloaded to a Toro Network 8000 unit (The Toro Co., Bloomington, Minn.). Iprodione [3-(3,5-dichlorophenyl)- $N$-(1-methylethyl)2,4-dioxo-1imadazolidinecarboximide] and chlorothalonil (tetrachloroisophthalonitrile) were applied as needed to suppress diseases. Once in both 2000 and 2001, dollar spot disease was allowed to develop to determine susceptibility of the grasses to the disease.

Treatment applications. The experimental design was a split-split plot, randomized complete-block with three replications. Treatments were applied in a factorial arrangement with 
grass type as whole plots $\left(16.7 \mathrm{~m}^{2}\right)$. Plots were split for aeration and topdressing beginning in May 1999. Core aration was conducted either once (October) or four times annually (May, July, September, October). Small diameter (0.6 $\mathrm{cm}$ ) tines were used except for the October aeration which used 1.3-cm-diameter tines. Cores were removed for each aeration and followed by topdressing. Topdressing was an 80 sand : 20 peat mixture that met USGA particle size specifications for putting green construction. Topdressing was applied either monthly, biweekly (2-week intervals) without verticutting, or biweekly immediately following verticutting. Topdressing was applied with a drop spreader calibrated to apply $0.4 \mathrm{~mm}$ depth, equivalent to $0.04 \mathrm{~m}^{3} \cdot 100 \mathrm{~m}^{-2}$ or 0.54 $\mathrm{kg} \cdot \mathrm{m}^{-2}$, for monthly treatments and at half-rate for biweekly treatments. The topdressing was brushed in after application and the turf was irrigated during the evening to replace daily ET loss. Data collection began in 2000 once plots had fully matured.

Data collection. Thatch production was measured using three cores $(2.5 \mathrm{~cm}$ diameter $\times$ $5 \mathrm{~cm}$ depth) collected from each plot in Oct. 2000 and 2001. The cores were compressed with a 185 -g weight, and the depth of the organic layer (thatch/mat) was measured at three equidistant points around the core. Measurements were averaged to provide one mean per replicate. Verdure and the bottom $2 \mathrm{~cm}$ of soil were removed from the cores, leaving mostly thatch and mat. Cores were allowed to air-dry for $21 \mathrm{~d}$ then placed in a forced-air oven at $44.4^{\circ} \mathrm{C}$ for $1 \mathrm{~h}$. Cores were weighed, combusted at $600^{\circ} \mathrm{C}$ for $2 \mathrm{~h}$, and reweighed to determine the amount of organic matter.

Topdressing particles removed by mowing the day following application were separated from clippings by adding water and decanting off the clippings. Topdressing samples were oven-dried at $60{ }^{\circ} \mathrm{C}$ for $24 \mathrm{~h}$ then weighed. Once in 2001 the collected and dried particles were segregated by passing through a nest of sieves to determine if the treatments affected particle size distribution of the sand removed. The mass of each particle size passing through a particular sieve size was divided by the fraction of that particle size in the original topdressing material to determine the percent fraction of topdressing removed by mowing. Particle size distribution of the original topdressing sand was determined from the average of sieving triplicate samples of $600 \mathrm{~g}$ each.

Plots were visually rated on a monthly basis for color, quality and disease severity. Color and quality were rated on a visual scale from one to nine, with one equal to $100 \%$ necrotic turf and nine equal to ideal turf. A rating of six was considered acceptable. A color rating of nine was equivalent to dark forest green and a color rating of one was equivalent to light green, almost yellow color. Quality was based on the uniformity of turf density and color, plus overall appearance, without regard to degree of green hue, saturation, or brilliance.

Three cores $(2.5 \mathrm{~cm}$ diameter $\times 5 \mathrm{~cm}$ depth $)$ were collected from each plot in the fall of 2000 and 2001. The cores were compressed with a 185 -g weight, and the depth of the organic layer (thatch/mat) was measured at three equidistant points on the core. Measurements were averaged to provide one mean per replicate. Once verdure was removed, the 2000 and 2001 cores were combusted at $600{ }^{\circ} \mathrm{C}$ for $2 \mathrm{~h}$ to determine the amount of organic matter similar to the American Society for Testing Materials (ASTM) D 2974-87 procedure.

Dollar spot severity was evaluated on 5 July 2000 and 5 Sept. 2001 following several days of intentionally uncontrolled disease development. Disease incidence was measured as the number of infection centers in each plot.

Data analysis. The amount of topdressing material removed by mowing was converted to percent of applied and averaged across all application dates for each year. Means of each replicate were used for statistical analysis. All data, including thatch and ratings, were analyzed as a randomized complete-block design with grass types as main plots, core aeration frequency as sub-plots, and topdressing regimes as sub-sub-plots (MSTAT, 1988). Treatment differences were separated by Fisher's protected least significant difference when $\mathrm{F}$ tests were significant at $P \leq 0.05$.

\section{Results and Discussion}

Thatch production. Grass type (main plot) was the only factor that affected thatch production (Table 1). Both 'A-4' and 'G-2' had >15 $\mathrm{mm}$ thatch in 2000 and $>23 \mathrm{~mm}$ thatch 2001 compared to $\leq 13 \mathrm{~mm}$ in 2000 and $<21 \mathrm{~mm}$ in 2001 for 'Penncross' and 'DW-184'. Differences in thatch mass among grass types was less dramatic than depth measurements, but followed similar trends with 'A-4' and 'G-2' having greater mass than 'Penncross', while 'DW-184' had similar biomass to the A and $\mathrm{G}$ bentgrasses. Thatch/mat mass differences between the A and $\mathrm{G}$ series bentgrasses and 'Penncross' were not as dramatic as those reported by Landry and Schlossberg (2001). Engel (1967) reported that high $\mathrm{N}$ fertility and aggressive growth produce excessive thatch in golf greens. In our study, plots received $\mathrm{N}$ at $17 \mathrm{~g} \cdot \mathrm{m}^{-2}$ annually, an amount similar to the low $\mathrm{N}$ rate used by Landry and Schlossberg (2001) which resulted in less thatch than $\mathrm{N}$ applied at 30 or more $\mathrm{g} \cdot \mathrm{m}^{-2}$ (Landry and Schlossberg, 2001). Thatch/mat depths may vary according to season leading to discrepancies in the literature. Sifers et al. (2001) reported 'Penncross' had thatch/mat depths similar to 'G-2', 'G-6', and 'A-1' creeping bentgrasses following a favorable spring growth period though 'Penncross' had significantly less thatch following a hot-humid summer stress period later that same year. In our study cores were collected near the end of the autumn season in both years following favorable growth conditions.

Neither sub-plot (aeration frequency) or sub-sub-plot (topdressing method) factors affected the thatch/mat depth of any of the cultivars. Both bimonthly and monthly topdressing regimes effectively diluted the thatch, resulting in mat as described in Beard (2002) as a visually obvious thatch layer was not present.
Table 1. Thatch/mat produced by four grass types maintained as putting green turf.

\begin{tabular}{lcclcc}
\hline Grass & \multicolumn{2}{c}{ Depth $(\mathrm{mm})$} & & \multicolumn{2}{c}{ Mass $^{\mathrm{z}}$} \\
\cline { 2 - 3 } \cline { 5 - 6 } type & 2000 & 2001 & & 2000 & 2001 \\
\hline & $-----\mathrm{mm}------$ & & $-----\mathrm{mg} \cdot \mathrm{cm}^{-3}------$ \\
A-4 & $15.9 \mathrm{~b}^{\mathrm{y}}$ & $23.0 \mathrm{c}$ & & $201.3 \mathrm{~b}$ & $184.0 \mathrm{bc}$ \\
G-2 & $16.5 \mathrm{~b}$ & $23.5 \mathrm{c}$ & & $194.7 \mathrm{~b}$ & $188.0 \mathrm{c}$ \\
Penncross & $13.0 \mathrm{a}$ & $16.9 \mathrm{a}$ & & $178.7 \mathrm{a}$ & $172.0 \mathrm{a}$ \\
DW-184 & $12.2 \mathrm{a}$ & $20.9 \mathrm{~b}$ & & $193.3 \mathrm{~b}$ & $178.7 \mathrm{~b}$ \\
LSD $_{0.05}$ & 2.0 & 1.6 & & 13.3 & 5.3 \\
\hline
\end{tabular}

${ }^{2}$ Based on weight loss upon ignition of two cores, $2.5 \mathrm{~cm}$ diameter $\times 3 \mathrm{~cm}$ depth, from each of four replications.

${ }^{y}$ Means followed by the same letter are not significantly different at $P<0.05$.

Topdressing removal. Main plot (grass type), sub-plot (core aeration frequency) and sub-sub-plot (topdressing regime) effects significantly $(P \leq 0.05)$ affected the amount of topdressing removed by mowing, although only $\approx 1 \%$ to $3 \%$ was removed from any single treatment. Statistically $(P \leq 0.05)$ more topdressing was removed from 'A-4' than 'DW$184^{\prime}(\approx 2 \%$ vs. $1 \%$ ) while losses from 'G-2' and 'Penncross' were intermediate (data not shown). Frequent core aeration resulted in $0.2 \%$ more topdressing removal than annual aeration in both years, although this was likely due to the root-zone mix being picked up by mowing following core aeration as there were no differences on dates when there was no core aeration. Biweekly topdressing with verticutting resulted in significantly $(P \leq 0.05)$ less topdressing loss $(1.3 \% \pm 0.2)$ than either biweekly or monthly applications without verticutting $(1.7 \% \pm 0$ and $2.0 \% \pm 0.3$, respectively). Grass type and topdressing method produced a significant interaction on the amount of topdressing removed in both years. Monthly topdressings resulted in significantly more loss than biweekly applications with verticutting for all cultivars except 'DW-184' in 2000 and ' $G-2$ ' in 2001 (Fig. 1 A and B). Biweekly topdressing without verticutting had intermediate results. No other interactions occurred regarding the amount of topdressing removed.

Grass type and topdressing method each significantly affected the distribution of particle sizes of topdressing removed by mowing in 2001. There were no interactions and core aeration frequency (sub-plot) did not affect size distribution of topdressing removed. Both 'A-4' and 'G-2' had $\approx 3 \%$ more of the larger-sized topdressing (1 to $2 \mathrm{~mm}$ ) particles removed compared to 'Penncross' (Table 2). Significantly $(P \leq 0.05)$ more of the mediumsized $(0.25$ to $0.5 \mathrm{~cm})$ particles were removed from 'Penncross' turf (35\%) than from either 'A-4' or ' G-2' turf (both $\approx 32 \%$ ). The mediumsized fraction accounted for over $65 \%$ of the total topdressing so differences in losses between grass types is potentially more important than differences in losses of the larger-sized particles.

Biweekly topdressing with verticutting resulted in less topdressing removed of all size fractions than monthly topdressing. Verticutting apparently served as expected to facilitate entry of topdressing particles into 


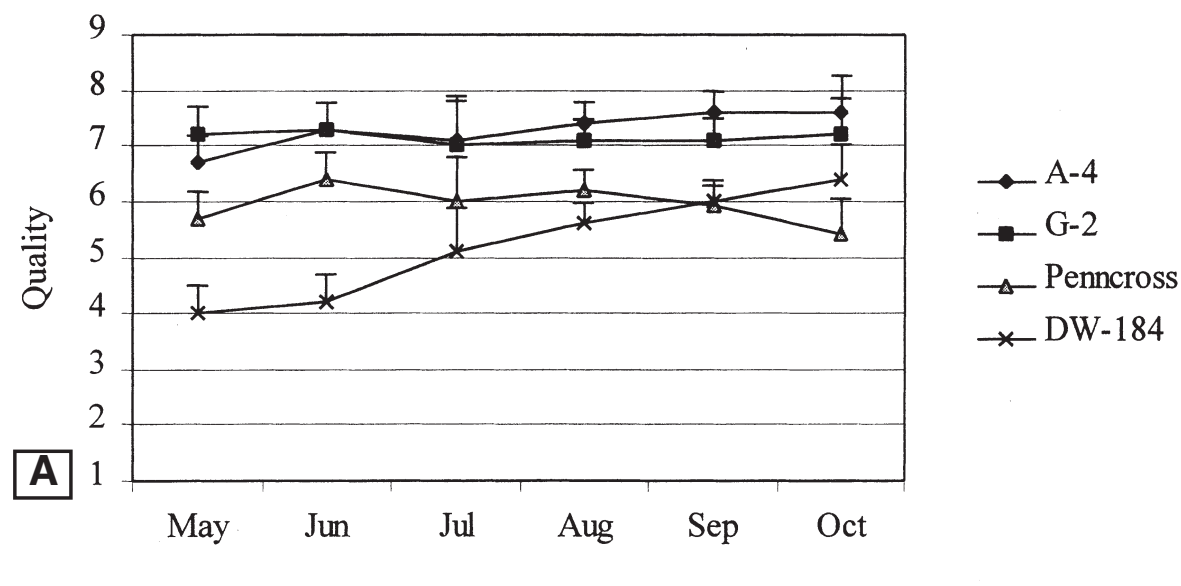

2000

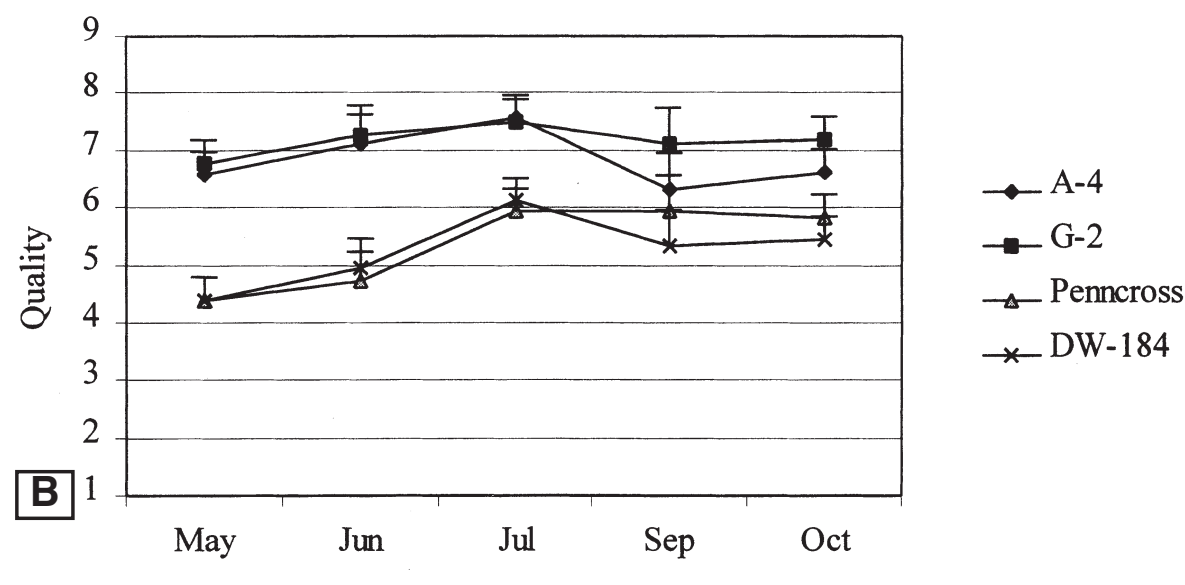

2001

Fig. 1. Interaction of cultivar type and topdressing regime on topdressing loss by mowing in (A) 2000 and (B) 2001. Creeping bentgrass cultivars are 'A-4', 'G-2', and 'Penncross'; 'DW-184' is a commercial variety of Poa annua var. reptans. Vertical bars represent the least significant difference (LSD) value for comparing treatment means $(P \leq 0.05)$ within and among cultivars.

Table 2. Particle size distribution of topdressing removed by mowing from four types of putting green turfgrasses and three topdressing regimes on 28 July 2001.

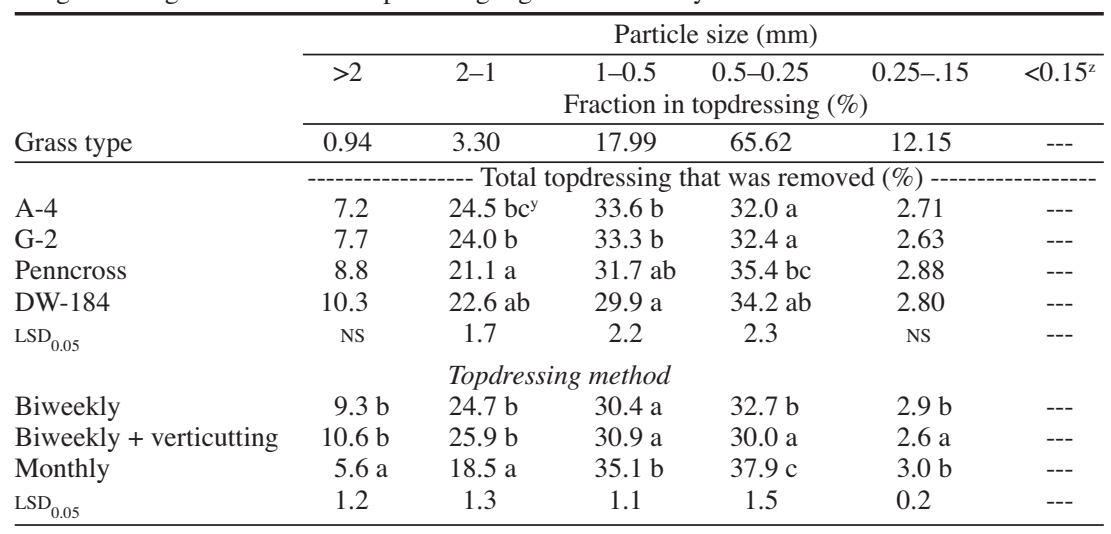

${ }^{2}$ There were no particles removed from this size range.

${ }^{\mathrm{y}}$ Means followed by the same letter are not significantly different at $P \leq 0.05$.

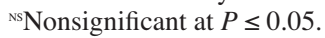

the turf by opening the canopy. Biweekly topdressing without verticutting gave intermediate results.

The slight differences in topdressing removal among grass types and topdressing treatments, although statistically significant, were unlikely to have any practical impact on turf management. Our topdressing rates were near the $50^{\text {th }}$ percentile for typical topdressing rates on greens (Beard, 2002), and our monthly application rates were half those used in a previous trial when topdressing was performed four times annually as in Sifers et al. (2001). In our study, the depth of topdressing applied during monthly applications was $\approx 12 \%$ that of the mowing height, while depths from biweekly applications were only $6 \%$ that of the mowing height. Information on topdressing removal by mowing could not be found for comparative purposes. It is probable, however, that a greater percentage of topdressing would be removed when applied at higher rates, or if the topdressing was not brushed and irrigated into the canopy prior to mowing.

Turf quality. Turf quality was dependent on grass types in both years and occasionally on topdressing method. Core aeration did not affect long-term turf quality and there were no regular interactions between or among grass type, core aeration, and topdressing method. Both 'A-4' and ' $\mathrm{G}-2$ ' creeping bentgrasses had similar turf quality and consistently provided better turf quality than either 'Penncross' or 'DW-184' (Fig. 2 A and B). Turf quality of 'DW-184' was significantly less than that of 'Penncross' during Spring 2000, but improved and was similar to 'Penncross' turf quality during the latter half of 2000 and all of 2001. Both 'Penncross' and 'DW-184' rarely provided acceptable turf quality (rating 6.0 or above) at the $3.2-\mathrm{mm}$ mowing height used in the study. The annual bluegrass 'DW-184' may have suffered from contamination with the annual biotype of annual bluegrass, P. annua var. annua L. Plots of ' DW184' exhibited profuse seedheads throughout the spring and summer of 1999 , a characteristic of annual biotypes while 'DW-184' has only seasonal flowering (Johnson et al., 1993). By late autumn the seedheads were largely gone, and there were relatively few seedheads in 2001. Due to the difficulty of producing 'DW-184' free of wild-type $P$. annua (Pepin, 2001), it is likely the original seed lot was contaminated with $P$. annua var. annua. The shift from season-long to spring-only flowering between 1999 and 2001 indicated the 'DW-184' perennial biotype was able to outcompete the suspected annual types on these closely mowed putting greens, similar to the competition phenomenon reported by Lush (1989).

The creeping bentgrass ' $\mathrm{A}-4$ ' consistently had darker green color $(\approx 8.0$ rating on a 1 to 9 scale) compared to all other grasses (data not shown). The creeping bentgrass 'G-2' often, but not always, exhibited darker color $(\approx 7.0)$ than 'Penncross' (6.0 to 7.0) and DW-184. Color of 'DW-184' was consistently lighter green in the spring than in the fall, changing from $\approx 4.0$ to 6.0 . As expected, core aeration and topdressing did not affect color of any turf cultivars (data not shown). 


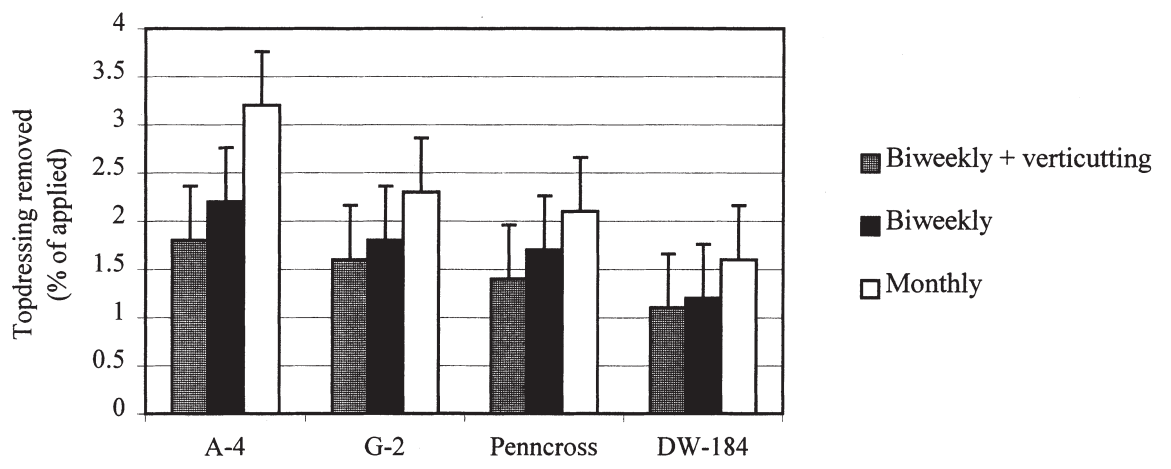

A

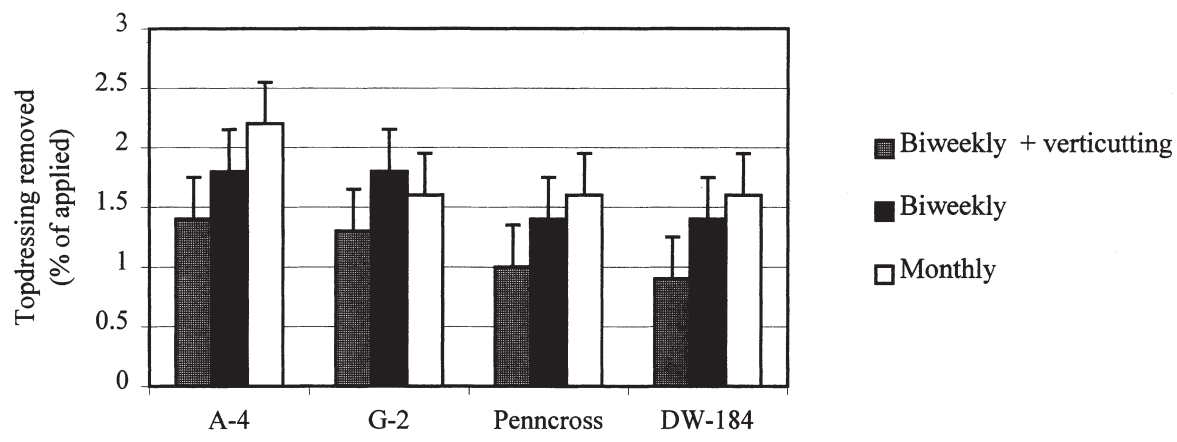

B

2001

Fig. 2. Quality of three creeping bentgrass cultivars and P. апnиa var. reptans 'DW-184' maintained at 3.2 $\mathrm{mm}$ height in (A) 2000 and (B) 2001. Quality was rated visually on a one to nine scale, with one equal to necrotic turf and nine equal to ideal turf; a rating of six was considered acceptable turf. Vertical bars represent the least significant difference value for comparing treatment means $(P \leq 0.05)$.

Dollar spot susceptibility. Dollar spot was readily controlled with fungicides. Dollar spot disease quickly developed when preventive applications ceased in both years. Significant differences in dollar spot incidence existed among the grass types while neither core aeration or topdressing had any effect. Annual bluegrass 'DW-184' was significantly more susceptible to dollar spot than 'Penncross' and 'G-2' creeping bentgrasses (Table 3). Previously, 'DW-184' was depicted as having dramatically superior dollar spot resistance compared to other creeping bluegrass clones (White, 1997), though it has not previously been compared to bentgrasses. Creeping bentgrass 'A-4' had significantly more dollar spot in both years than either 'Penncross' and 'G-2' and was similar to 'DW-184' in 2001. The dramatic differences in occurrence of dollar spot among the bentgrasses disagreed with results from the southeastern U.S. which reported 'A-4', 'G-2', and 'Penncross' all had relatively good dollar spot resistance (Bruneau et al., 2001). Our results may have differed due to different strains of the pathogen, though the limited evidence available suggests pathogenicity of $S$. homeocarpa isolates varies according more to host species rather than cultivar (Hsiang et al., 2000). However, other data from trials in various regions of the United States have also noted a lack of dollar spot resistance in 'A-4' compared to 'Penncross', similar to results in our study (NTEP, 1997). Seasonal
Table 3. Incidence of dollar spot (Sclerotinia homeocarpa) on turfs maintained as putting greens.

\begin{tabular}{lcc}
\hline & \multicolumn{2}{c}{ No. of dollar spot patches per plot } \\
\cline { 2 - 3 } Cultivar & 5 July 2000 & 5 Sept. 2001 \\
\hline A-4 & $19.1 \mathrm{~b}$ & $35.2 \mathrm{bc}$ \\
G-2 & $5.2 \mathrm{a}$ & $9.2 \mathrm{ab}$ \\
Penncross & $0.3 \mathrm{a}$ & $6.8 \mathrm{a}$ \\
DW-184 & $71.6 \mathrm{c}$ & $49.7 \mathrm{c}$ \\
LSD $_{0.05}$ & 7.9 & 26.3 \\
\hline
\end{tabular}

of the mowing height. Information on topdressing removal by mowing could not be found for comparative purposes. It is probable, however, that a greater percentage of topdressing would be removed when applied at higher rates, or if the topdressing was not brushed and irrigated into the canopy prior to mowing.

Subterranean organic matter production. Grass types were the only treatment variable that affected subterranean organic matter production. Since even the monthly topdressing application effectively diluted the organic matter it cannot properly be termed thatch but as mat (Beard, 2002). Both A-4 and G-2 produced greater depths of organic matter in both 2000 and 2001 compared to both Penncross and DW-184 (Table 3). Differences in biomass production among grass types was less dramatic than depth measurements but followed similar trends with A-4 and G-2 having greater subterranean mass than Penncross in 2000 and DW-184 in 2001. Mat/thatch biomass differences between the $\mathrm{A}$ and $\mathrm{G}$ bentgrasses and Penncross were not as dramatic as those reported by Landry and Schlossberg (2001). Engel (1967) reported that high $\mathrm{N}$ fertility and aggressive growth produce excessive thatch in golf greens. In our study, plots received 17 $\mathrm{g} \cdot \mathrm{m}^{-2}$ of $\mathrm{N}$ annually, an amount similar to that discussed by Landry and Schlossberg (2001) as contributing to less thatch development than 30 or more $\mathrm{g} \cdot \mathrm{m}^{-2}$ of N. Data from spring and fall measurements of mat/thatch depth in a single year showed that G-2, G-6, and A-1 did not necessarily produce deeper mat/thatch layer than Penncross (Sifers et al., 2001).

\section{Conclusions}

Core aeration and topdressing requirements for 'A-4' and 'G-2' do not seem to deviate significantly from traditional regimes for bentgrasses. Both 'A-4' and 'G-2' produced more thatch than 'Penncross' or 'DW-184', but the thatch was diluted similarly among grass species by both bimonthly and monthly topdressing applications. The amount of topdressing removed from any grass type was minimal, rebutting concerns that the density of $A$ and $G$ series bentgrasses affects topdressing removal. Both 'A-4' and 'G-2' provided consistently better turf quality at 3.2-mm cutting height than either 'Penncross' or 'DW-184' creeping bluegrass. Other mowing heights and management practices such as irrigation timing may produce different results than those reported here. Characteristics such as green speed, divot recovery, and ball marks were not evaluated due to spatial constraints but may be affected by grass type, core aeration, and topdressing regime. 


\section{Literature Cited}

Beard, J.B. 1999. Poa annua terminology clarified. Turfax 7(4):3.

Beard, J.B. 2002. Turf management for golf courses, $2^{\text {nd }}$ ed. Ann Arbor Press, Chelsea, Mich.

Beard,J.B.,P.Croce, M. Mocioni, A. De Luca, and M. Volterrani. 2001. The comparative competitive ability of thirteen Agrostis stolonifera cultivars to Poа аппиа. Intl. Turfgrass Soc. Res. J. 9: 828-831.

Bruneau, A.H., C.A. Bigelow, R.J. Cooper, and D.C. Bowman. 2001. Performance of creeping bentgrass cultivars maintained at two mowing heights and under two fungicide regimes in North Carolina. Intl. Turfgrass Soc. Res. J. 9: 835-842.

Dudek, A.E. and S.F. Anderson. 1999. Overseed rates for establishment of creeping and rough bluegrass, p. 133. In: Agronomy abstracts. ASA, CSSA, SSSA, Madison, Wisc.

Engel, R.E. 1967. A note on the development of puffiness in quarter inch bentgrass turf with varied nitrogen fertilization. New Jersey Agr. Expt. Sta. Bul. 818:46-49.

Fraser, M.L. 1997. Susceptibility of creeping bent- grasses to dollar spot, 1994. Biological and Cultural Tests for Control of Plant Dis. 12:125.

Fraser, M.L. 1998. Managing the new cultivars of creeping bentgrass. Golf Course Mgt. 66(8): 53-56.

Hsiang, T., X.L. Ma, L. Yang, and S. Cook. 2000. Analyses of RAPD data for detection of host specialization in Sclerotinia homeocarpa. Plant Pathol. 49(2):269-275.

Huff, D.R. 1998. The case for Poa аппиа on golf course greens. Golf Course Mgt. 66(10):1-3.

Johnson, P.G., B.A. Ruemmele, P. Velguth, D.B. White, and P.D. Ascher. 1993. An overview of Poa annua L. reproductive biology. In: R.N. Carrow, N.E. Christians, and R.C. Shearman (eds.). Intl. Turfgrass Soc. Res. J. 7:798-804. Intertec Publishing Corp., Overland Park, Kans.

Landry, G., and M. Schlossberg. 2001. Bentgrass (Agrostis spp.) cultivar performance on a golf course putting green. Intl. Turfgrass Soc. Res. J. 9:886-897.

Lush, W.M. 1989. Adaptation and differentiation of golf course populations of annual bluegrass (Poa апnиa). Weed Sci. 37:54-59.

Miltner, E., P. Backman, and G. Stahnke. 2000 Establishment of Peterson Seeds creeping bluegrass (Poa reptans). Turfgrass Mgt. in the Pacific Northwest 3(1):16-17.

MSTAT-C. 1988. User's guide to MSTAT-C. Michigan State Univ., East Lansing.

National Turfgrass Evaluation Program (NTEP). 1997. National Creeping Bentgrass trials [online]. Available at http//:www.NTEP.org (verified 10 May 2002).

Pepin, J. 2001. New species and cultivars for golf $71^{\text {st }}$ Annu. Michigan Turfgrass Conf. Proc. 30: 83-85. 15-18 Jan. 2001, East Lansing.

Powell, J.F. and J.M. Vargas, Jr. 2001. Vegetative compatibility and seasonal variation among isolates of Sclerotinia homeocarpa. Plant Dis. 85(4):377-381.

Sifers, S.I., J.B. Beard, and M.L. Fraser. 2001. Botanical comparisons of twelve Agrostis cultivars in a warm-humid climate. Intl. Turfgrass Soc. Res. J. 9:213-217.

USGA. 1993. Recommendations for a method of putting green construction. USGA Green Section Record 31(2):1-3.

White, D. 1997. Improvement of Роа аппиа var. reptans for golf turf. USGA 1997 Turfgrass and Environ. Res. Summary, Far Hills, N.J. p. 31-32. 